\title{
Biological Hydrogen Production from Amphora sp. Isolated from Eastern Coast of Thailand
}

\author{
$W$ Jangiam $^{1}, P$ Tongtubtim ${ }^{1}$ and $M$ Penjun $^{1}$ \\ ${ }^{1}$ Department of Chemical Engineering, Faculty of Engineering, Burapha University, Chonburi, 20131, Thailand
}

\begin{abstract}
The world is finding ways of producing fuel from many sources to replace the fossil fuels. Hydrogen is considered one of the most promising fuels for the future. One biological way of producing hydrogen from solar energy is using photosynthetic microorganisms. The objective of this study is to search for marine algae which produce hydrogen and study the appropriate conditions to produce hydrogen from marine algae. Firstly, the 5 strains of algae were studied the total gas production. Amphora sp. was selected and studied the appropriate conditions to produce hydrogen gas. The first condition, we studied the important factors for marine algae which were present and absent sulfur. The second condition was to find the suitable $\mathrm{pH}$ for producing hydrogen which were $\mathrm{pH} 7, \mathrm{pH} 8$ and $\mathrm{pH} 9$. The last condition, we studied the optimal light intensity which were 481, 1075 and 2085 lux. The result showed that Amphora sp. can produce hydrogen gas in present sulfur media, $\mathrm{pH} 8$ and light intensity 2085 lux in volume $495.3 \mathrm{ml}$ per $1 \mathrm{~L}$ of algae or the average rate of produce hydrogen is $0.798 \mathrm{ml}$ per $\mathrm{g}$ of algae per hour.
\end{abstract}

\section{Introduction}

When it comes to looking for the energy source that will replace fossil fuels, there is no shortage of options. The hydrogen is an alternative energy that can be used to replace conventional energy. The features of hydrogen are a clean energy because when the fuel cell will not release carbon dioxide out [1-3], so it does not cause global warming [4] to burn high and not cause air pollution [5]. The use of algae in the production of hydrogen is because algae are plants different from extra fuel is generally faster in photosynthesis [6], algae can bring solar energy used in photosynthesis faster than other alternative crops and can be cultured without a lot of trouble [6]. After cultured, algae can be used as fertilizer, animal feed substance, cosmetic or even used as medicine.

Some green microalgae, such as Chlamydomonasreinhardtii [7] and Chlorella salina [8] produce hydrogen via direct photolysis [9]. Hydrogen gas evolution in algae requires a certain period of anaerobic incubation to induce the reversible hydrogenase. The hydrogenase then functions to combine electrons and protons to form hydrogen gas [10-17]. However, despite extensive research, this process has low yields and is rather feeble. A study by other investigators isolated a unicellular hydrogen-producing green alga, Tetrasporasp., from freshwater pond in Thailand with efficient hydrogen production [18]. However, it is even more preferable to have organisms to generate hydrogen using seawater because they do not require arable land and do not affect fresh water resources, can be produced using the ocean. It is important to find the native species of marine algae that should suitable for cultivation and hydrogen production. Our study is an initial step designed to fill this gap.In this work, we collected and isolated the marine algae which have the ability to produce the hydrogen gas to find the suitable conditions. The conditions that we tested were sulfur deprivation, $\mathrm{pH}$, and light intensity.

\section{Material and method}

\subsection{Algal cultures}

The hydrogen producing culture was enriched from a sample collected from the eastern coast of Thailand. Many species of marine algae were collected during low tide by hand-picking from the coast of Chanthaburi Province, Thailand and purified by plating, streaking, and single colony picking. The collected marine algae were identified by morphological identification method. All algal cells were grown aerobically under constant shaking at $25{ }^{\circ} \mathrm{C}$ under fluorescent light (2085 lux). Marine algal cells were grown under continuous light in Tris-acetatephosphate (TAP) medium at $\mathrm{pH}$ 8.0.

\subsection{Algal growth conditions}

All algal cells were grown aerobically under constant shaking at $25^{\circ} \mathrm{C}$ under fluorescent light. Marine algal cells were grown under continuous light in TAP medium, $\mathrm{pH}$ 8.0. 


\subsection{Hydrogen evaluation}

In the linear growth phase ( 15 to $25 \mu \mathrm{g} \mathrm{Chl}^{-1} \times \mathrm{ml}^{-1}$ ), algal cells were harvested, then transferred into squared glass bottles, sealed with a gas-tight septum and exposed to 2085 lux.After total gas production, total gas was used to evaluate the hydrogen volume by replacing a total gas with $1.2 \mathrm{~mol} / \mathrm{l} \mathrm{NaOH}$ and $0.85 \mathrm{~mol} / 1 \mathrm{MnCl}_{2}$. Sodium hydroxide and manganese chloride would trap the $\mathrm{O}_{2}$ from the total gas [19].

\section{Result}

\subsection{Total gas production}

Total gas production volume for each alga was measured by water replacement method. The information generated was used in selecting the best algae for hydrogen production. Production of total gas by Anacystis sp., and Amphora sp. increased only slightly during $0-20 \mathrm{~h}$ (Figure 1). Total gas production increased rapidly during 20-30 hours, and finally became stable in 30-40 hours. Anacystis $s p$. was the highest gas producing strain of the group at the last stage. The total gas production of Cheatoseros sp. increased during 0-3 hours and became stable thereafter, followed by a small final increase. Tetraselmis $s p$. and Nitzchia sp. cultures did not show any gas production.Amphora $s p$., was selected to be tested for further experiment because of the high volume of biological hydrogen production at the first stage (0-40 hours).

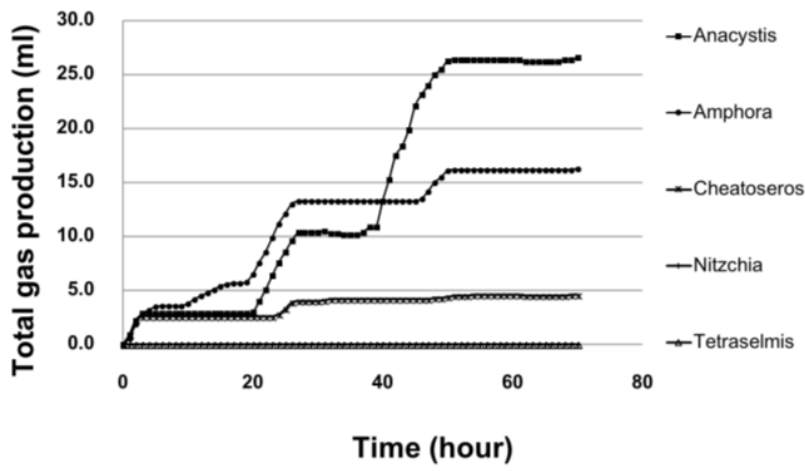

Fig. 1. The relationship between the gas volume and time for all the algae.

\subsection{Effect of composition of sulfur in the medium on hydrogen yield}

A suitable method, developed in order to produce sustainable hydrogen, has been reported where the process is handled in 2 stages. Algae were grown in TAP medium, washed and transferred to TAP or TAP-S (Sdeprived) medium and $\mathrm{pH}$ were 8.3. From Figure 2, a graph showed hydrogen production of Amphora. $s p$ every 1 hour. Results showed that there were 3 stages of hydrogen production in unchanged medium. The first stage was $0-24$ hours, the second stage was $25-47$ hours, and third stages was 48-67 hours. The highest hydrogen production time was at 67 hours which produced 148.6 $\mathrm{ml}$. However, the hydrogen increased continuously at all stages in unchanged medium. On the other hand, previous studied have shown an increased hydrogen production in cells cultivated in S-deprived conditions during the production phase [20].

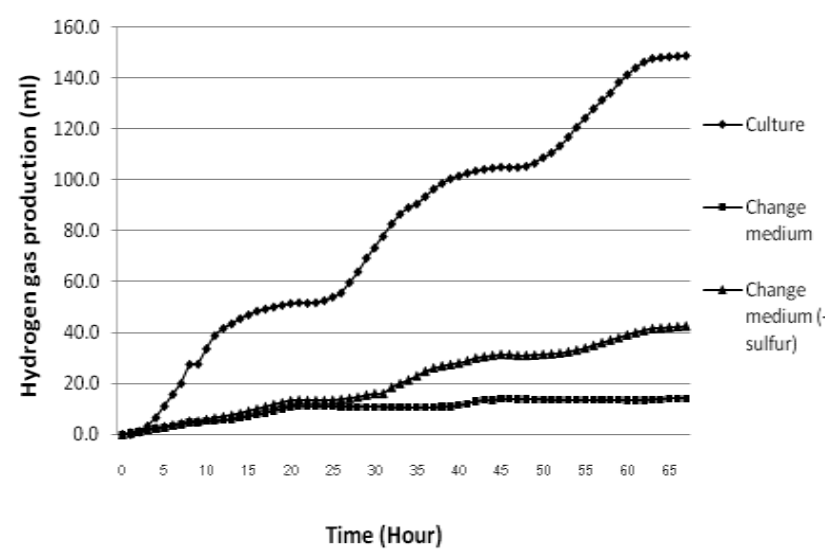

Fig. 2. The graph shows the relationship between time with the amount of hydrogen of Amphora. sp. in the medium that has no sulfur and sulfur.

\subsection{Effect of $\mathrm{pH}$ on hydrogen yield}

To examine the dependence of hydrogen evolution on $\mathrm{pH}$, Amphora sp. cells were grown in TAP medium for 5 days, washed and transferred to medium at desired $\mathrm{pH}(7,8,9)$ and then illuminated under the light. This experiment was designed to know the condition of acid-base which effects on hydrogen production. In this test, we adjusted the $\mathrm{pH}$ of the medium to 7,8 and 9 before inoculation. From Figure 3, a graph showed hydrogen production of Amphora sp. every 1 hour in the differentpH. The hydrogen production was highest at $\mathrm{pH}$ 8. In this condition, the hydrogen gas was $68.5 \mathrm{ml}$ in 60 hoursor the average rate of produce hydrogen is $1.151 \mathrm{ml}$ per $\mathrm{g}$ of algae per hour.

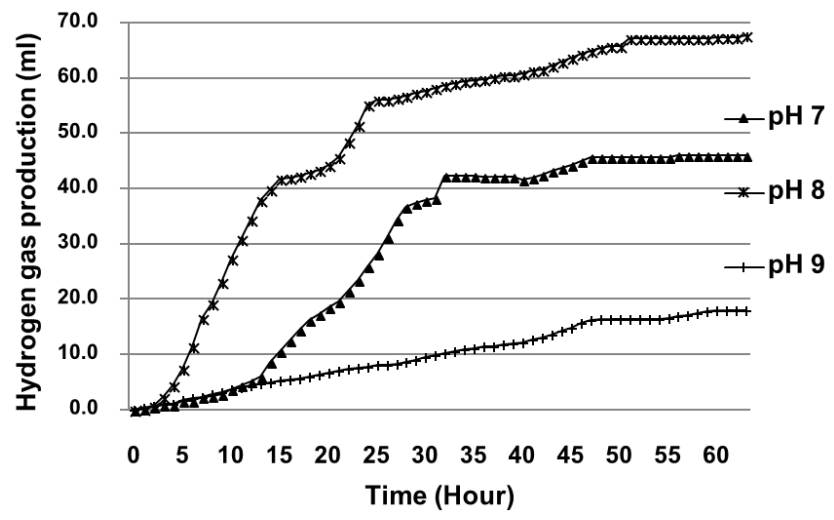

Fig. 3. The graph shows the relationship between time with the amount of hydrogen of Amphora sp. in the different $\mathrm{pH}$.

\subsection{Effect of light intensity on hydrogen yield}


This experiment was to find the suitable light intensity because of the amount of light effect on the growth and photosynthesis of the algae. To find the suitable light intensity for optimal production of hydrogen, the algae were subjected to light exposure at various intensities (481, 1076, 2085 lux).From Figure 4, the light intensity of 2085 lux Amphora sp. algae could produce hydrogen at the highest volume.

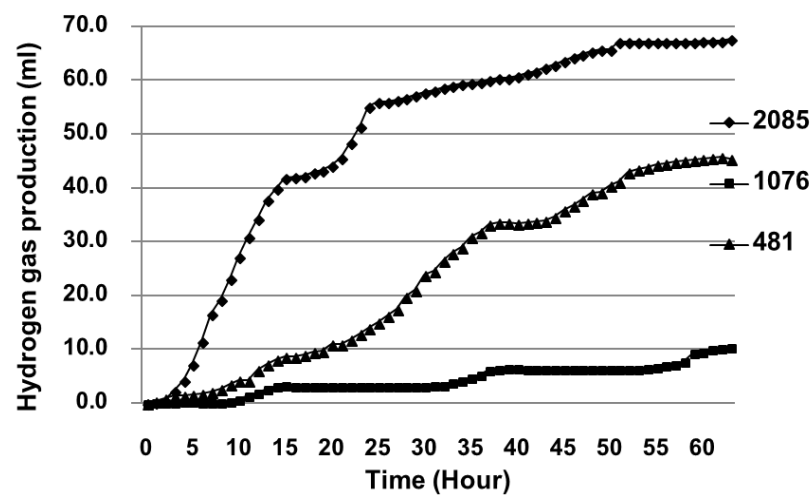

Fig. 4. The graph shows the relationship between time with the amount of hydrogen of Amphora sp. in the different light intensity.

\section{Discussion and Conclusion}

The optimum condition of Amphora sp. to have the high volume of hydrogen gas was a medium which was continued from the medium growth. The result showed that Amphora sp. grown in unchanged medium in Figure 2 was the best condition to produce hydrogen gas in $\mathrm{pH} 8$ and light intensity 2085 lux in volume $495.3 \mathrm{ml}$ per $1 \mathrm{~L}$ of algae or the average rate of produce hydrogen was $0.798 \mathrm{ml}$ per $\mathrm{g}$ of algae per hour.

In many cases, the certain dark period was also necessary for conversion of sugars into alcohol and other metabolite formation including hydrogen. Generally certain species and strains of Chlorella, Chlamydomonas, Nannochloropsis etc. tolerate light fluctuations and exhibits the high growth rate including yield [21]. Generally, acidic condition alters the morphology of algal cells and limits the motility of Euglena mutabilis and Chlamydomonasapplanata [22]. Low $\mathrm{pH}$ condition limits the nutrient uptake which leads to the reduction of photosynthetic ability thereby decreasing the accumulation of total carbon and evolution of oxygen [23]. However, a significant method of hydrogen production is not developed for the massive level. The enhancementof biological hydrogen production would be focused on usingvarious environmental and biochemical approaches because it would help us to understand theresponse of Amphora sp. in different environmental conditionswith respect to hydrogen production.

\section{Acknowledgement}

This work was supported in part by the research grant, contract number 34/2553, from Faculty of Engineering, Burapha University.

\section{Reference}

1. D. Dutta, D. De, S. Chaudhuri, and S. K. Bhattacharya, "Hydrogen production by Cyanobacteria", Microbial Cell Factories. 4: 36, 2005.

2. H. Zhang, M. A. Brunsb, B. E. and Logana, "Biological hydrogen production by Clostridium acetobutylicum in an unsaturated flow reactor.", Water Research. 40: 728 - 734, 2006.

3. X. Tian, Q. Liao, W. Liu, Y. Z. Wang, X. Zhu, J. Li, and H. Wang, "Photo-hydrogen production rate of a PVA-boric acid gel granule containing immobilized photosynthetic bacteria cells" International Journal of Hydrogen Energy. 34: 4708-4717. 2009.

4. S. V. Ginkel, and S. Sung, "Biohydrogen Production as a Function of $\mathrm{pH}$ and Substrate Concentration", Environ. Sci. Technol. 35: 4726-4730, 2001.

5. D. Madamwar, N. Garg, and V. Shah, "Cyanobacterial hydrogen production", World Journal of Microbiology \& Biotechnology. 16: $757-$ 767, 2000.

6. E. Greenbaum, and J. W. Lee, "Photosynthetic hydrogen and oxygen production by green algae: an overview", Plenum Press, London, 1998.

7. S. Kosourov, A. Tsygankov, M. Seiber, M. L. Ghirardi, "Sustained hydrogen photoproduction by Chlamydomonasreinhardtii: effects of culture parameters", Biotechnology and Bioengineering. 78: 731-740, 2002.

8. S. Chader, H. Hacene, S. N. Agathos, "Study of hydrogen production by three strains of Chlorella isolated from the soil in the Algerian Sahara", International Journal of Hydrogen Energy. 34: 49414946, 2009.

9. A. Melis, "Green alga hydrogen production: progress, challenges and prospects", International Journal of Hydrogen Energy. 27: 1217-1228, 2002.

10. E. Greenbaum, J. W. Lee, "Photosynthetic hydrogen and oxygen production by green algae: an overview", Plenum Press, London. 1998.

11. E. Greenbaum, "Photosynthetic hydrogen and oxygen production: kinetic studies", Science. 196: 879-990, 1982.

12. T. Happe, B. Mosler, J. D. Naber, "Induction, localization and metal content of hydrogenase in Chlamydomonasreinhardtii", European Journal of Biochemistry. 222: 769-774, 1994.

13. F. H. Yildiz, J. P. Davies, A. R. Grossman, "Characterization of sulfate transport in Chlamydomonasreinhardtii during sulfur-limited and sulfur-sufficient growth", Plant Physiology. 104: 981-987, 1994. 
14. S. M. Plummer, M. A. Plummer, P. A. Merkel, M. Hagen, J. F. Biddle, L. A. Waidner "Using direct evolution to improve hydrogen production in chimeric hydrogenases from Clostridia species", Enzyme and Microbial Technology. 93-94: 132-141, 2016.

15. J. A. Birrell, O. Rudiger, E. J. Reijerse, W. Lubitz. "Semisynthetic Hydrogenase Propel Biological Energy Research into a New Era", Joule. 1(1): 61-76, 2017.

16. G. Lakatos. D. Balogh, A. Farkas, V. Ordog, P. T. Nagy, T. Biro, G. Maroti. "Factors influenzing algal photobiohydrogen production in algal-bacterial cocultures", Algal Research. 28:161-171, 2017.

17. K. Paramesh, N. L. Reddy, M. V. Shankar, T. Chandrasekhar. "Enhancement of Biological hydrogen production using green alga Chlorococcumminutum", International Journal of Hydrogen Energy. 43:3957-3966, 2018.

18. C. Maneeruttanarungroj, P. Lindblad, A. Incharoensakdi. "A newly isolated green alga, Tetraspora sp. CU2551, from Thailand with efficient hydrogen production", International Journal of Hydrogen Energy. 35(24): 13193-13199, 2010.
19. P. Tongtubtim, M. Peanjun, "The screening of marine algae and finding the optimal conditions for hydrogen gas production", B.Sc. Thesis. Department of Chemical Engineering, Faculty of Engineering, Burapha University, Thailand, 2010.

20. T. K. Antal, T. E. Krendeleva, T. V. Laurinavichene, V. V. Makarova, M. L. Ghirardi, A. B. Rubin, et al. "The dependence of algal $\mathrm{H} 2$ production on Photosystem II and $\mathrm{O} 2$ consumption activities in sulfur-deprived Chlamydomonasreinhardtii cells", BiochemBiophysActaBioenerg. 1607: 153-60, 2003.

21. A. Juneja, R. M. Ceballos, G. S. Murthy. "Effects of environmental factors and nutrient availability on the biochemical composition of algae for biofuels production", A Rev Energies. 6:4607-4638, 2013.

22. J. Hargreaves, B. A. Whitton. "Effect of $\mathrm{pH}$ on growth of acid stream algae", Eur J Phycol. 11:215223, 1976.

23. J. R. Coleman, B. Colman. "Inorganic carbon accumulation and photosynthesis in a blue-green algae as a function of external $\mathrm{pH}$ ", Plant Physiol. 67:917-21, 1981 